\title{
Risks and benefits of hypotensive resuscitation in patients with traumatic hemorrhagic shock: a meta-analysis
}

\author{
Natthida Owattanapanich ${ }^{1}$, Kaweesak Chittawatanarat ${ }^{2}$, Thoetphum Benyakorn ${ }^{3}$ and Jatuporn Sirikun ${ }^{\text {* }}$
}

\begin{abstract}
Background: Damage control strategies play an important role in trauma patient management. One such strategy, hypotensive resuscitation, is being increasingly employed. Although several randomized controlled trials have reported its benefits, the mortality benefit of hypotensive resuscitation has not yet been systematically reviewed.

Objectives: To conduct a meta-analysis of the efficacy of hypotensive resuscitation in traumatic hemorrhagic shock patients relative to mortality as the primary outcome, with acute respiratory distress syndrome (ARDS), acute kidney injury (AKI), and multiple organ dysfunction as the secondary outcomes.

Methods: PubMed, Medline-Ovid, Scopus, Science Direct, EMBASE, and CNKI database searches were conducted. An additional search of relevant primary literature and review articles was also performed. Randomized controlled trials and cohort studies reporting the mortality rate associated with hypotensive resuscitation or limited fluid resuscitation were selected. The random-effects model was used to estimate mortality and onset of other complications.

Results: Of 2114 studies, 30 were selected for this meta-analysis. A statistically significant decrease in mortality was observed in the hypotensive resuscitation group (risk ratio [RR]: 0.50; 95\% confidence interval [Cl]: 0.40-0.61). Heterogeneity was observed in the included literature $\left(1^{2}: 27 \%\right.$; degrees of freedom: $\left.23 ; p=0.11\right)$. Less usage of packed red cell transfusions and fluid resuscitations was also demonstrated. No significant difference between groups was observed for AKl; however, a protective effect was observed relative to both multiple organ dysfunction and ARDS.

Conclusions: This meta-analysis revealed significant benefits of hypotensive resuscitation relative to mortality in traumatic hemorrhagic shock patients. It not only reduced the need for blood transfusions and the incidences of ARDS and multiple organ dysfunction, but it caused a non-significant AKI incidence.
\end{abstract}

Keywords: Thailand, Hypotensive resuscitation, Traumatic hemorrhagic shock patients, Meta-analysis

\section{Introduction}

Hemorrhagic shock is one of the most common causes of death in trauma or traumatized patients [1]. This is due to the fact that hemorrhagic shock sets in motion a vicious cycle of outcomes, consisting of hypothermia, acidosis, and coagulopathy-otherwise known as the lethal triad. To mitigate these effects, damage control strategies have been proposed, including the early control of bleeding and adequate fluid resuscitation. The aim of hypotensive

\footnotetext{
* Correspondence: j_sirikun@hotmail.com

'Division of Trauma Surgery, Department of Surgery, Faculty of Medicine, Siriraj hospital, Mahidol University, 2 Wanglang Road, Bangkok Noi, Bangkok 10700, Thailand

Full list of author information is available at the end of the article
}

resuscitation is to maintain systolic blood pressure (or mean arterial pressure) in order to sustain organ perfusion $[2,3]$. It was believed that induced intraoperative hypotension could lead to reduced blood loss and fewer transfusions [4-6]. However, much recent data have shown that there is a significant relationship between hypotensive resuscitation and postoperative renal injuries [7-9].

Fluid resuscitation with the rapid administration of intravenous fluids until the blood pressure is normalized is the traditional fluid-resuscitation strategy. A number of randomized controlled trials have demonstrated some improvement in survival and mortality using a liberal fluid hypotensive resuscitation. Nevertheless, other studies have concluded that a more conservative hypotensive 
strategy-in which minimal amounts of fluids are given until the severe bleeding has been controlledis a more efficacious resuscitation strategy [10-13]. Although the volume of data on hypotensive resuscitation continues to grow, conflicting findings are being reported regarding the efficacy of this traumamitigating strategy. Accordingly, the aim of this study was to conduct a meta-analysis of the efficacy and drawbacks of hypotensive resuscitation in traumatic hemorrhagic shock patients relative to mortality as the primary outcome, with acute respiratory distress syndrome, acute kidney injury, and multiple organ dysfunction as the secondary outcomes.

\section{Methods}

\section{Inclusion criteria}

This meta-analysis included only randomized controlled trials (RCTs) and cohort studies that evaluated adult patients aged older than 18 years who had traumatic hemorrhagic shock and a systolic blood pressure below $90 \mathrm{mmHg}$.

The intervention assessed was conventional fluid resuscitation with normotension (liberal fluid resuscitation) versus hypotensive resuscitation (limited fluid resuscitation). Conventional fluid resuscitation was defined as liberal fluid resuscitation until the systolic blood pressure exceeded $90 \mathrm{mmHg}$ (normal blood pressure). Hypotensive resuscitation was defined as limited fluid resuscitation to maintain adequate organ perfusion, with a systolic blood pressure of $\sim 70-80 \mathrm{mmHg}$ or a mean arterial pressure of $\sim 50 \mathrm{mmHg}$.
Excluded were studies of patients who were pregnant or had traumatic brain injuries, research with insufficient mortality data, and investigations that had not received ethical approval.

\section{Outcomes assessed}

The primary outcome was all-cause mortality, as reported by the authors of the included studies. The secondary outcomes included the rates of the following morbidities: acute respiratory distress syndrome (ARDS), acute kidney injury (AKI), and multiple organ dysfunction (MODS). Other secondary outcomes included the fluid resuscitation volume and the transfusion of packed red cells.

\section{Search methods}

PubMed, Medline-Ovid, Scopus, Science Direct, EMBASE, and CNKI database searches were conducted for articles published before January 31, 2018. An additional search of relevant primary literature and review articles was also performed. The references from identified studies that appeared to be germane to the topic of study were hand-searched. The medical subject headings (MeSHs) used in our searches included "hypotensive resuscitation" or "limited fluid resuscitation" and "trauma" or "trauma". There was no language restriction.

\section{Data collection}

Two reviewers (N.O. and T.B.) independently inspected each article identified during the search, scanned the full text of relevant articles, applied the inclusion and exclusion criteria, and extracted and

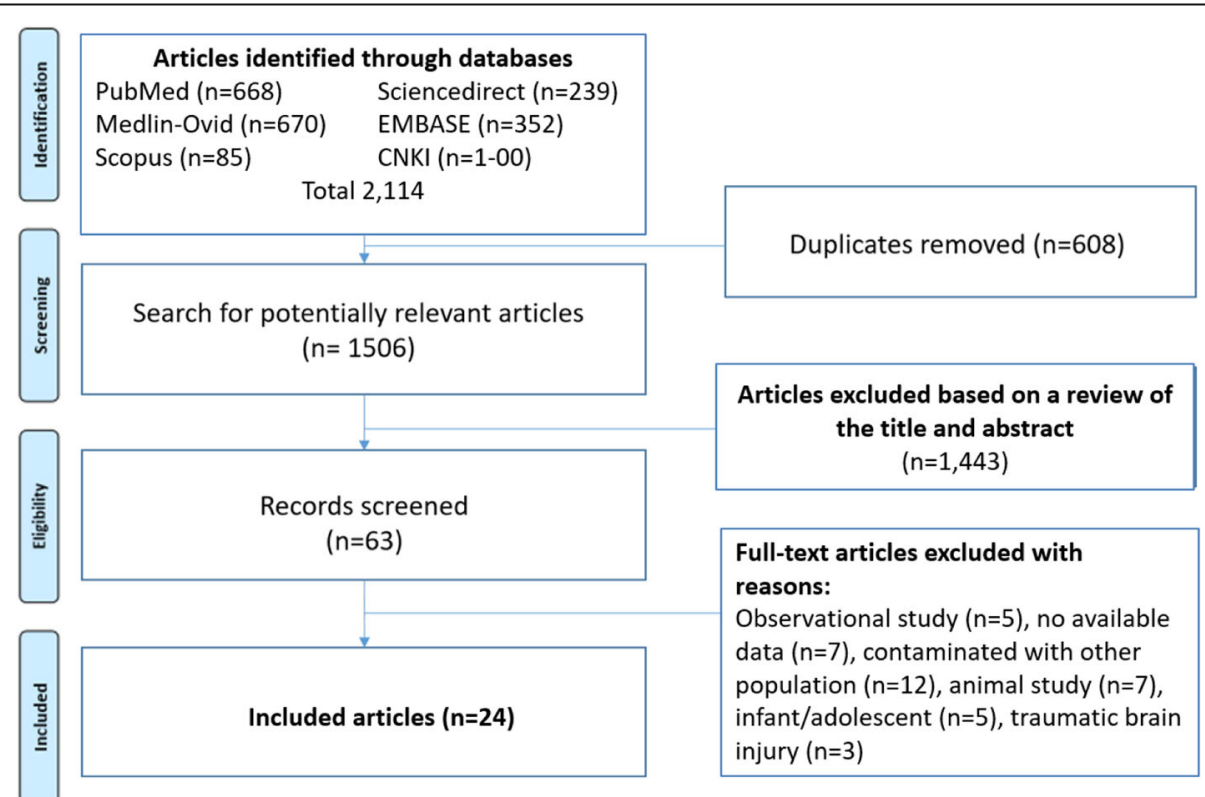

Fig. 1 Flow diagram of the article selection procedure based on the Preferred Reporting Items for Systematic Reviews and Meta-Analyses (PRISMA) guideline 
Table 1 Study characteristics

\begin{tabular}{|c|c|c|c|c|c|c|}
\hline Study & Country & Study design & $\begin{array}{l}\text { Jadad Quality score/ } \\
\text { Newcastle-Ottawa } \\
\text { scale (NOS) }\end{array}$ & Participants & Intervention & Control \\
\hline Bickell 1994 & USA & $\begin{array}{l}\text { Single-center, } \\
\text { prospective RCT }\end{array}$ & $\begin{array}{l}\text { Three out of five } \\
\text {-No double blind }\end{array}$ & $\begin{array}{l}\text { Gunshot or stab wounds } \\
\text { to the torso who had } \\
\text { SBP }<90 \mathrm{mmHg}\end{array}$ & $\begin{array}{l}\text { Delayed resuscitation } \\
\text { with RLS } 10 \mathrm{ml} / \mathrm{hr} \\
\text { until definitive } \\
\text { treatment }\end{array}$ & $\begin{array}{l}\text { Immediate resuscitation } \\
\text { to maintain SBP at least } \\
100 \mathrm{mmHg}\end{array}$ \\
\hline Dutton 2002 & USA & $\begin{array}{l}\text { Single-center, } \\
\text { prospective RCT }\end{array}$ & $\begin{array}{l}\text { Three out of five } \\
\text {-No double blind }\end{array}$ & $\begin{array}{l}\text { Traumatic hemorrhagic } \\
\text { shock with SBP }<90 \\
\text { mmHg and evidence } \\
\text { of ongoing bleeding }\end{array}$ & $\begin{array}{l}\text { Low SBP of } 70 \\
\mathrm{mmHg}\end{array}$ & $\begin{array}{l}\text { Conventional SBP }>100 \\
\mathrm{mmHg}\end{array}$ \\
\hline $\begin{array}{l}\text { WANG Mei- } \\
\text { tang } 2007\end{array}$ & China & $\begin{array}{l}\text { Single-center, } \\
\text { prospective } \\
\text { cohort study }\end{array}$ & $\begin{array}{l}\text { Selection: } 3 \\
\text { Comparability: } 2 \\
\text { Outcome: } 2\end{array}$ & $\begin{array}{l}\text { Traumatic hemorrhagic } \\
\text { shock }\end{array}$ & $\begin{array}{l}\text { Preoperative SBP } \\
\text { approximately } \\
70-80 \mathrm{mmHg}\end{array}$ & $\begin{array}{l}\text { Preoperative SBP }>90 \\
\mathrm{mmHg}\end{array}$ \\
\hline $\begin{array}{l}\text { ZHENG Wei- } \\
\text { hua } 2007\end{array}$ & China & $\begin{array}{l}\text { Single-center, } \\
\text { prospective, RCT }\end{array}$ & $\begin{array}{l}\text { Two out of five } \\
\text {-No method of } \\
\text { randomization } \\
\text {-No double blind }\end{array}$ & $\begin{array}{l}\text { Traumatic hemorrhagic } \\
\text { shock patients }\end{array}$ & $\begin{array}{l}\text { Limited fluid } \\
\text { resuscitation (MAP } \\
50-60 \mathrm{mmHg} \text { ) }\end{array}$ & $\begin{array}{l}\text { Aggressive fluid } \\
\text { resuscitation (MAP } 70 \\
\mathrm{mmHg} \text { ) }\end{array}$ \\
\hline $\begin{array}{l}\text { HUA Li-dain } \\
2010\end{array}$ & China & Prospective, RCT & $\begin{array}{l}\text { Two out of five } \\
\text {-No method of } \\
\text { randomization } \\
\text {-No double blind }\end{array}$ & $\begin{array}{l}\text { Severe multiple hemorrhagic } \\
\text { shock }\end{array}$ & $\begin{array}{l}\text { Limited fluid } \\
\text { resuscitation } \\
\text { (SBP } 70 \mathrm{mmHg} \text { ) }\end{array}$ & $\begin{array}{l}\text { Observational with MAP } \\
\text { at least } 90 / 60 \mathrm{mmHg}\end{array}$ \\
\hline $\begin{array}{l}\text { WANG Aitian } \\
2010\end{array}$ & China & Prospective, $\mathrm{RCT}$ & $\begin{array}{l}\text { Two out of five } \\
\text {-No method of } \\
\text { randomization } \\
\text {-No double blind }\end{array}$ & Traumatic hemorrhagic shock & $\begin{array}{l}\text { Limited fluid } \\
\text { resuscitation to } \\
\text { maintain SBP } 70 \\
\text { mmHg }\end{array}$ & $\begin{array}{l}\text { Conventional resuscitation } \\
\text { to maintain SBP } 100 \\
\mathrm{mmHg}\end{array}$ \\
\hline $\begin{array}{l}\text { Fan Hai-Peng } \\
2011\end{array}$ & China & Prospective, RCT & $\begin{array}{l}\text { Two out of five } \\
\text {-No method of } \\
\text { randomization } \\
\text {-No double blind }\end{array}$ & $\begin{array}{l}\text { Pelvic fracture with hemorrhagic } \\
\text { shock }\end{array}$ & $\begin{array}{l}\text { Low MAP } 50-60 \\
\mathrm{mmHg} \text { or SBP } \\
70-90 \mathrm{mmHg}\end{array}$ & $\begin{array}{l}\text { Conventional MAP } 60-80 \\
\mathrm{mmHg} \text { or SBP }>100 \\
\mathrm{mmHg}\end{array}$ \\
\hline Morrison 2011 & China & $\begin{array}{l}\text { Single-center, } \\
\text { prospective, } \\
\text { two-arm, } \\
\text { intention to } \\
\text { treat, RCT }\end{array}$ & $\begin{array}{l}\text { Three out of five } \\
\text {-No double blind }\end{array}$ & $\begin{array}{l}\text { Patients undergoing laparotomy } \\
\text { or thoracotomy for blunt and } \\
\text { penetrating trauma who had } \\
\text { SBP }<90 \mathrm{mmHg}\end{array}$ & $\begin{array}{l}\text { Experimental group } \\
\text { with MAP } 50 \mathrm{mmHg}\end{array}$ & $\begin{array}{l}\text { Control group with MAP } \\
65 \mathrm{mmHg}\end{array}$ \\
\hline $\begin{array}{l}\text { Fan Hai-Peng } \\
2012\end{array}$ & China & $\begin{array}{l}\text { Single-center, } \\
\text { RCT }\end{array}$ & $\begin{array}{l}\text { Two out of five } \\
\text {-No method of } \\
\text { randomization } \\
\text {-No double blind }\end{array}$ & $\begin{array}{l}\text { Hepatic and splenic injury with } \\
\text { hemorrhagic shock }\end{array}$ & $\begin{array}{l}\text { Limited fluid } \\
\text { resuscitation } \\
\text { (MAP 50-60 } \\
\text { mmHg) }\end{array}$ & $\begin{array}{l}\text { Conventional resuscitation } \\
\text { (SBP } 100 \mathrm{mmHg} \text { or MAP } \\
60-80 \mathrm{mmHg} \text { ) }\end{array}$ \\
\hline $\begin{array}{l}\text { LI Wenhao } \\
2012\end{array}$ & China & Prospective, RCT & $\begin{array}{l}\text { Two out of five } \\
\text {-No method of } \\
\text { randomization } \\
\text {-No double blind }\end{array}$ & $\begin{array}{l}\text { Traumatic hemorrhagic shock } \\
\text { without controlling bleeding }\end{array}$ & $\begin{array}{l}\text { Limited fluid } \\
\text { resuscitation } \\
\text { (MAP } 55 \mathrm{mmHg} \text { ) }\end{array}$ & $\begin{array}{l}\text { Adequate fluid } \\
\text { resuscitation (MAP } \\
75 \mathrm{~mm} \mathrm{Hg} \text { ) }\end{array}$ \\
\hline $\begin{array}{l}\text { Chen Mu-hu } \\
2013\end{array}$ & China & Prospective, $\mathrm{RCT}$ & $\begin{array}{l}\text { Two out of five } \\
\text {-No method of } \\
\text { randomization } \\
\text {-No double blind }\end{array}$ & $\begin{array}{l}\text { Traumatic hemorrhagic shock } \\
\text { patients }\end{array}$ & $\begin{array}{l}\text { Limited fluid } \\
\text { resuscitation } \\
\text { (SBP } 70 \mathrm{mmHg} \text { ) }\end{array}$ & $\begin{array}{l}\text { Aggressive fluid } \\
\text { resuscitation (SBP } \\
90 \mathrm{mmHg} \text { ) }\end{array}$ \\
\hline $\begin{array}{l}\text { ZHAO yong- } \\
\text { gang } 2013\end{array}$ & China & $\begin{array}{l}\text { Retrospective } \\
\text { cohort study }\end{array}$ & $\begin{array}{l}\text { Selection: } 4 \\
\text { Comparability: } 2 \\
\text { Outcome: } 2\end{array}$ & $\begin{array}{l}\text { Traumatic hemorrhagic shock } \\
\text { patients }\end{array}$ & $\begin{array}{l}\text { Objective group } \\
\text { (SBP } 85 \mathrm{mmHg} \text {, } \\
\text { limited fluid) }\end{array}$ & $\begin{array}{l}\text { Control group (SBP } \\
>90 \mathrm{mmHg} \text {, rapid } \\
\text { and full replenishment } \\
\text { of fluid }\end{array}$ \\
\hline $\begin{array}{l}\text { WANG Xiao- } \\
\text { guo } 2014\end{array}$ & China & Prospective, RCT & $\begin{array}{l}\text { Two out of five } \\
\text {-No method of } \\
\text { randomization } \\
\text {-No double blind }\end{array}$ & $\begin{array}{l}\text { Traumatic liver and splenic } \\
\text { injury }\end{array}$ & $\begin{array}{l}\text { Limited fluid } \\
\text { resuscitation } \\
\text { (MAP } 50-70 \mathrm{mmHg} \text { ) }\end{array}$ & $\begin{array}{l}\text { Conventional resuscitation } \\
\text { (MAP } 70-90 \mathrm{mmH} \text { ) }\end{array}$ \\
\hline $\begin{array}{l}\text { ZENG Fan- } \\
\text { yuan } 2014\end{array}$ & China & $\begin{array}{l}\text { Single-center, } \\
\text { cohort study }\end{array}$ & $\begin{array}{l}\text { Selection: } 4 \\
\text { Comparability: } 2 \\
\text { Outcome: } 2\end{array}$ & $\begin{array}{l}\text { Uncontrolled traumatic } \\
\text { hemorrhagic shock patients }\end{array}$ & $\begin{array}{l}\text { Experimental group } \\
\text { (MAP } 50 \mathrm{mmHg} \text { ) }\end{array}$ & $\begin{array}{l}\text { Control group (MAP } 70 \\
\mathrm{mmHg} \text { ) }\end{array}$ \\
\hline $\begin{array}{l}\text { Chen } \\
\text { Mianzhan } \\
2015\end{array}$ & China & Prospective, $\mathrm{RCT}$ & $\begin{array}{l}\text { Two out of five } \\
\text {-No method of } \\
\text { randomization }\end{array}$ & $\begin{array}{l}\text { Traumatic hemorrhagic shock } \\
\text { patients }\end{array}$ & $\begin{array}{l}\text { Limited resuscitation } \\
\text { (SBP at least } 80 \\
\mathrm{mmHg} \text { ) }\end{array}$ & $\begin{array}{l}\text { Conventional resuscitation } \\
\text { (SBP at least } 90 \mathrm{mmHg} \text { ) }\end{array}$ \\
\hline
\end{tabular}


Table 1 Study characteristics (Continued)

\begin{tabular}{|c|c|c|c|c|c|c|}
\hline Study & Country & Study design & $\begin{array}{l}\text { Jadad Quality score/ } \\
\text { Newcastle-Ottawa } \\
\text { scale (NOS) }\end{array}$ & Participants & Intervention & Control \\
\hline & & & -No double blind & & & \\
\hline $\begin{array}{l}\text { Chen Yuan- } \\
\text { bing, } 2015\end{array}$ & China & Prospective, $\mathrm{RCT}$ & $\begin{array}{l}\text { Two out of five } \\
\text {-No method of } \\
\text { randomization } \\
\text {-No double blind }\end{array}$ & $\begin{array}{l}\text { Traumatic hemorrhagic shock } \\
\text { patients }\end{array}$ & $\begin{array}{l}\text { Limited resuscitation } \\
\text { (SBP } 70 \mathrm{mmHg} \text { ) }\end{array}$ & $\begin{array}{l}\text { Conventional resuscitation } \\
(\mathrm{SBP}>90 \mathrm{mmHg})\end{array}$ \\
\hline $\begin{array}{l}\text { Huang Ting } \\
2015\end{array}$ & China & Prospective, $\mathrm{RCT}$ & $\begin{array}{l}\text { Two out of five } \\
\text {-No method of } \\
\text { randomization } \\
\text {-No double blind }\end{array}$ & Traumatic hemorrhagic shock & $\begin{array}{l}\text { Control group with } \\
\text { MAP } 40-60 \mathrm{mmHg}\end{array}$ & $\begin{array}{l}\text { Observation group with } \\
\text { MAP } 60-90 \mathrm{mmHg}\end{array}$ \\
\hline $\begin{array}{l}\text { Schreiber } \\
2015\end{array}$ & USA & $\begin{array}{l}\text { Multi-center, } \\
\text { RCT }\end{array}$ & $\begin{array}{l}\text { Three out of five } \\
\text {-No double blind }\end{array}$ & $\begin{array}{l}\text { Blunt or penetrating trauma } \\
\text { patients with SBP }<90 \\
\mathrm{mmHg}\end{array}$ & $\begin{array}{l}\text { Administer } 250 \mathrm{ml} \\
\text { of fluid if SBP }<70 \\
\mathrm{mmHg} \text { or absent } \\
\text { radial pulse }\end{array}$ & $\begin{array}{l}\text { Administer } 2 \text { liters initially } \\
\text { and additional fluid as } \\
\text { needed to maintain } \\
\text { SBP }>110 \mathrm{mmHg}\end{array}$ \\
\hline $\begin{array}{l}\text { Wen Zhen-jie } \\
2015\end{array}$ & China & $\begin{array}{l}\text { Multi-center, } \\
\text { prospective } \\
\text { cohort studies }\end{array}$ & $\begin{array}{l}\text { Selection: } 4 \\
\text { Comparability: } 2 \\
\text { Outcome: } 2\end{array}$ & Traumatic hemorrhagic shock & $\begin{array}{l}\text { Limited fluid } \\
\text { resuscitation (SBP } \\
75 \mathrm{mmHg} \text { ) }\end{array}$ & $\begin{array}{l}\text { Conventional fluid } \\
\text { resuscitation (SBP > } \\
100 \mathrm{mmHg} \text { ) }\end{array}$ \\
\hline $\begin{array}{l}\text { XU Guoping } \\
2015\end{array}$ & China & $\begin{array}{l}\text { Single center, } \\
\text { prospective } R C T\end{array}$ & $\begin{array}{l}\text { Two out of five } \\
\text {-No method of } \\
\text { randomization } \\
\text {-No double blind }\end{array}$ & $\begin{array}{l}\text { Traumatic hemorrhagic shock } \\
\text { patients }\end{array}$ & $\begin{array}{l}\text { Limited fluid } \\
\text { resuscitation (MAP } \\
40-60 \mathrm{mmHg} \text { or SBP } \\
70 \mathrm{mmHg} \text { ) }\end{array}$ & $\begin{array}{l}\text { Conventional resuscitation } \\
\text { (MAP } 60-80 \mathrm{mmHg} \text { or } \\
\text { SBP }>90 \mathrm{mmHg} \text { ) }\end{array}$ \\
\hline $\begin{array}{l}\text { YAO Jian-hui } \\
2015\end{array}$ & China & $\begin{array}{l}\text { Single center, } \\
\text { prospective, RCT }\end{array}$ & $\begin{array}{l}\text { Two out of five } \\
\text {-No method of } \\
\text { randomization } \\
\text {-No double blind }\end{array}$ & $\begin{array}{l}\text { Multiple traumatic hemorrhagic } \\
\text { shock patients }\end{array}$ & $\begin{array}{l}\text { Limited fluid } \\
\text { resuscitation (MAP } \\
40-50 \mathrm{mmHg} \text { ) }\end{array}$ & $\begin{array}{l}\text { Active fluid resuscitation } \\
\text { (MAP } 60-80 \mathrm{mmHg} \text { ) }\end{array}$ \\
\hline Carrick 2016 & USA & $\begin{array}{l}\text { Single-center, } \\
\text { prospective, } \\
\text { two-arm, } \\
\text { intention-to- } \\
\text { treat, RCT }\end{array}$ & $\begin{array}{l}\text { Three out of five } \\
\text {-No double blind }\end{array}$ & $\begin{array}{l}\text { Penetrating trauma patients } \\
\text { with SBP }<90 \mathrm{mmHg} \text { who } \\
\text { were brought emergently } \\
\text { to OR for bleeding control }\end{array}$ & $\begin{array}{l}\text { Keep low MAP (MAP } \\
50 \mathrm{mmHg} \text { ) }\end{array}$ & $\begin{array}{l}\text { Keep normotension } \\
\text { (MAP at least } 65 \text { mmHg) }\end{array}$ \\
\hline $\begin{array}{l}\text { Dai Yulong, } \\
2016\end{array}$ & China & Prospective, RCT & $\begin{array}{l}\text { Two out of five } \\
\text {-No method of } \\
\text { randomization } \\
\text {-No double blind }\end{array}$ & $\begin{array}{l}\text { Traumatic hemorrhagic shock } \\
\text { patients }\end{array}$ & $\begin{array}{l}\text { Limited fluid } \\
\text { resuscitation (SBP } \\
65 \mathrm{mmHg} \text { ) }\end{array}$ & $\begin{array}{l}\text { Conventional resuscitation } \\
\text { (SBP } 90 \mathrm{mmHg} \text { ) }\end{array}$ \\
\hline $\begin{array}{l}\text { Wang } \\
\text { Fengyong } \\
2016\end{array}$ & China & $\begin{array}{l}\text { Single center, } \\
\text { prospective RCT }\end{array}$ & $\begin{array}{l}\text { Two out of five } \\
\text {-No method of } \\
\text { randomization } \\
\text {-No double blind }\end{array}$ & Active hemorrhagic shock & $\begin{array}{l}\text { Limited fluid } \\
\text { resuscitation } \\
\text { (maintain MAP } \\
40-60 \mathrm{mmHg} \text { ) }\end{array}$ & $\begin{array}{l}\text { Conventional resuscitation } \\
\text { (maintain MAP 60-90 } \\
\mathrm{mmHg} \text { ) }\end{array}$ \\
\hline
\end{tabular}

recorded the data. Disagreements relating to any aspect of the data extraction process were resolved by discussion with a third reviewer (K.C.), with the final decision made by consensus.

\section{Quality assessment}

The quality of included studies was evaluated using the Jadad quality assessment scale for randomized controlled studies. Our subsequent analysis only included those studies that scored $\geq 2$ on the scale (which indicated that their results were valid) [14]. To assess the quality of nonrandomized studies, the Newcastle-Ottawa Scale (NOS) was used. This 3-item scoring system evaluates the selection of the participants; the comparability between the groups; and the ascertainment of exposure for case-control studies, and the outcome of interest in the case of cohort studies [15].

\section{Statistical analysis}

All statistical analyses were performed using Review Manager 5.3 software from the Cochrane Collaboration (London, United Kingdom). We extracted the proportions and 95\% confidence intervals from each study and pooled them using the random effects model. Cochran's Q test was performed and quantified using the $I^{2}$ statistic to evaluate the statistical heterogeneity among the included studies. The $I^{2}$-values were categorized as follows: $0-25 \%$ indicated insignificant heterogeneity; 26-50\%, low heterogeneity; $>50 \%$ to $\leq 75 \%$, moderate heterogeneity; and $>75 \%$, high heterogeneity [16]. The fixed effects model was 
used for analyses that evaluated data with no significant heterogeneity. Funnel plots were used to evaluate for publication bias. $P$-values less than 0.05 were considered statistically significant.

\section{Results}

Search results and study characteristics

Figure 1 illustrates a flow diagram describing the article selection process, which was based on the Preferred Reporting Items for Systematic Reviews and Meta-Analyses (PRISMA) guidelines. Our review of the literature yielded 2114 publications up to January 31, 2018. For an assortment of reasons during the article selection process, 2090 of those articles were excluded. The specific reasons for exclusion are given in Fig. 1. The remaining 24 studies were included in the final analysis $[2,10-13,17-35]$. Of those 24 studies, 20 were randomized controlled trials, while 4 were prospective cohort studies. The baseline characteristics described in Table 1 comprise country, article type, the quality assessment score for each study, and the intervention definition.

\section{Assessment of reporting bias}

A funnel plot of the reporting bias shows asymmetry on visual inspection (Fig. 2). There were 3 studies with low statistically significant effects (risk ratio [RR]: $0.11 ; 95 \%$ confidence interval [CI]: 0.01-0.75; Zhao Yong-gang, 2013 [34], Dai Yulong, 2016 [20], and Wang Fengyong, 2016 [27]). These studies give the plot an asymmetrical appearance, with a gap at a bottom corner of the graph. In this setting, the effect calculated in a meta-analysis will tend to overestimate the intervention effect. However, after reviewing the study design and evaluating the outcomes, we still decided to include them in our analysis.

The Egger test found a strong significance in publication bias $(P=0.000)$ Therefore, the trim and fill method was conducted to adjust the publication bias by removing the smaller studies causing asymmetry and replacing the omitted studies. This method has been claimed to improve the effect size and confidence intervals [36]. As a result, the present study drew upon 11 hypothesized studies. The new RR was 0.65 and CI (0.52-0.80), which showed significant difference in mortality benefit (Fig. 3).

\section{Synthesis of primary outcome}

A pooled analysis was performed of the 24 studies using a random-effects model, with findings reported as RR and 95\% CI $(n=1473$; RR: 0.50 ; 95\% CI: 0.40 0.61 ). A mild heterogeneity among these 24 studies was observed ( $\mathrm{Q}$ test: 0.11 , which is greater than 0.1 ; $\left.I^{2}: 27 \%\right)$. Given the degree of homogeneity among the studies, a random-effects model was subsequently applied (Fig. 4). As described in Fig. 4, some overtime bias was observed among the studies. Although the first published study on this topic (by Bickell WH et al. [2]) was published in 1994, we still included it due to its sound methodology and overall high level of quality.

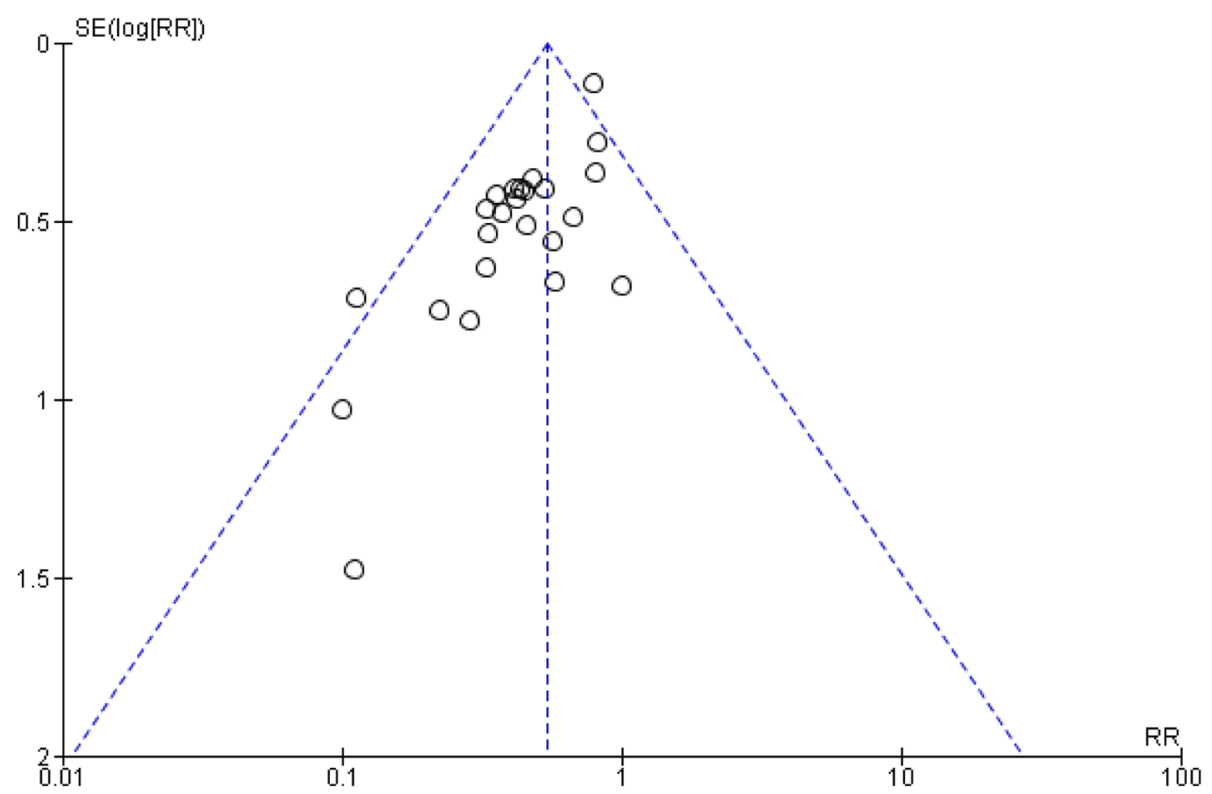

Fig. 2 Funnel plot of reporting bias (the dotted lines indicate the 95\% confidence interval [Cl]; SE, standard error; RR, risk ratio) 


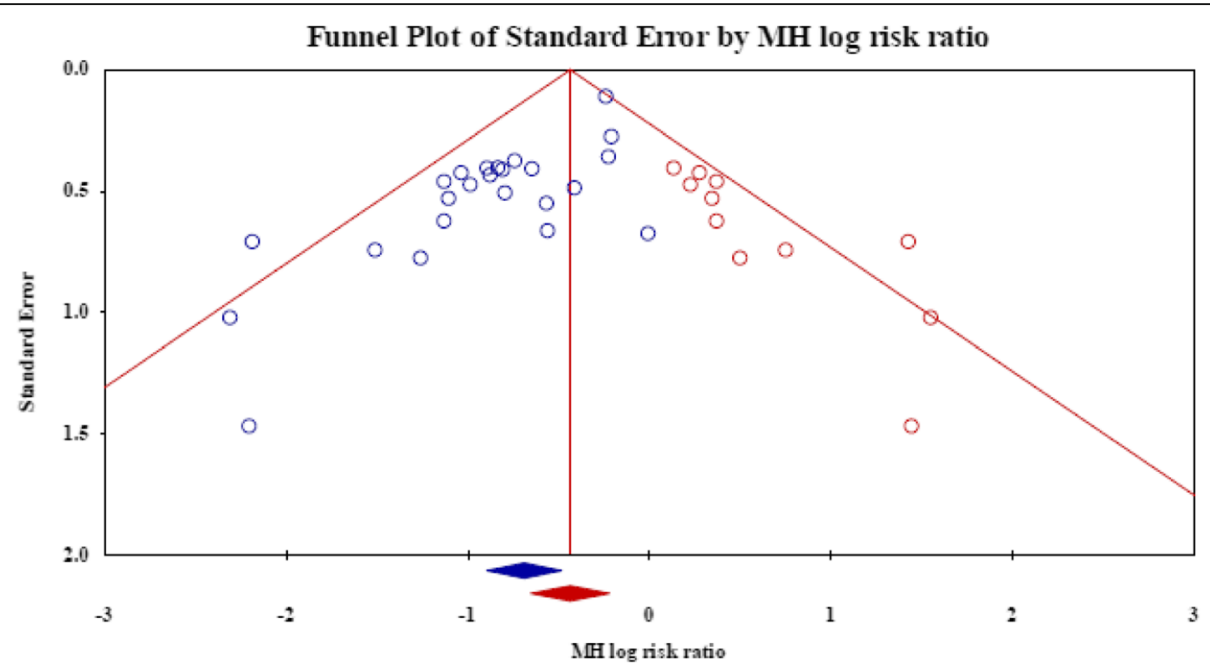

Fig. 3 The funnel plot after trim and fill method

\section{Secondary outcomes}

The hypotensive resuscitation group had a lower amount of fluid resuscitation and packed red cell transfusion than the normotensive resuscitation group (Figs. 5 and 6). The mean difference in fluid resuscitation between groups was 1233 $\mathrm{ml}$ (95\% CI: -1576, -890) and red cell transfusion was 132 $\mathrm{ml}(95 \% \mathrm{CI}:-203,-61)$.
In terms of the possible risks of this hypotensive strategy, 7 studies [2, 13, 17, 18, 23, 28, 33] showed that the hypotensive resuscitation group had no significant difference in acute kidney injury (RR: 1.19; 95\% CI: 0.65, 2.21; Fig. 7). This strategy also had lower incidences of both acute respiratory distress syndrome (RR: 0.44; 95\% CI: 0.33, 0.59) and multiple

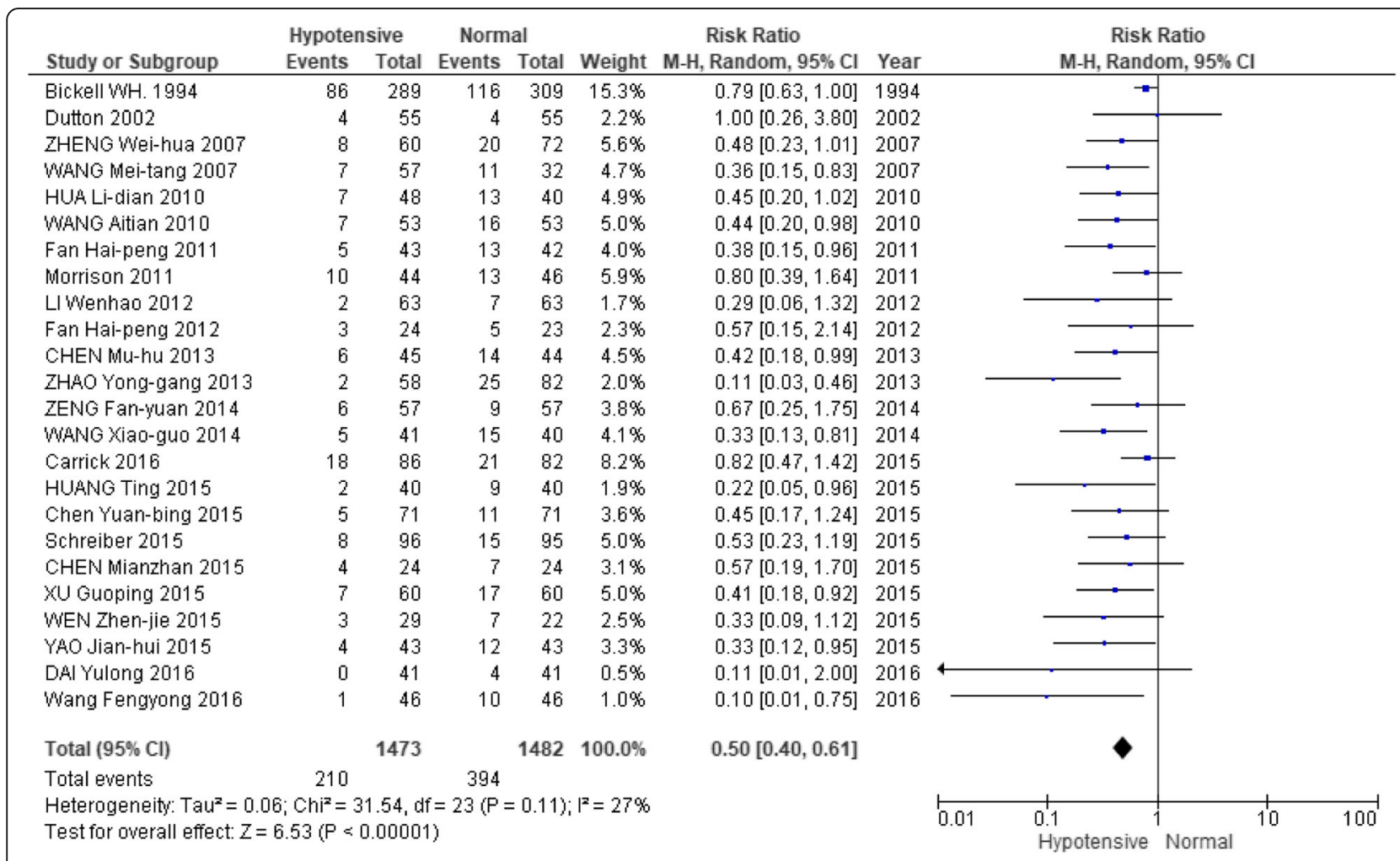

Fig. 4 Forest plot of association between hypotensive resuscitation and normal resuscitation, relative to mortality 


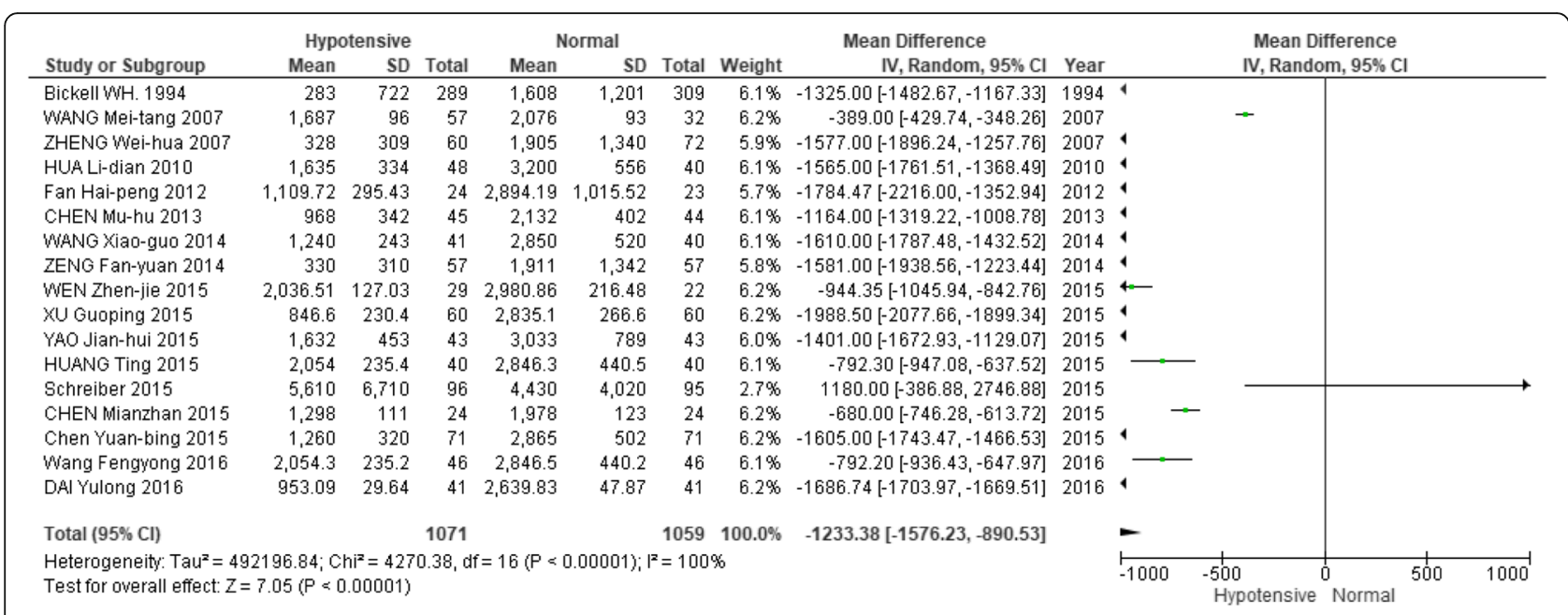

Fig. 5 Forest plot of association between hypotensive resuscitation and normal resuscitation, relative to fluid resuscitation volume

organ dysfunction (RR: 0.40; 95\% CI: 0.26, 0.61; Figs. 8 and 9).

\section{Discussion}

During the last decade, two differing approaches to damage control have been used for severe trauma patients. The traditional liberal fluid approach has, however, come under increasing attention due to the possible complications associated with administering more than 21 of fluid before surgery. In contrast, hypotensive resuscitation is being increasingly emp loyed because many animal studies have found its use is associated with reduced effects of the lethal triad. The concept of this strategy is to restrict the amount of fluid resuscitation to maintain a low enough blood pressure for adequate cerebral perfusion. To avoid further bleeding due to dilution coagulopathy and to dislodge hemostatic blood clots, hypotensive resuscitation has been adopted as a part of damage control resuscitation for trauma patients [37, 38]. Bickell WH et al. were the first to study and publish the role of hypotensive resuscitation in penetrating trauma patients. They showed that hypotensive resuscitation before surgery could significantly decrease mortality. Not only did the fatality rate decrease, but the hypotensive resuscitation also appeared to correlate with less coagulopathy and other complications, including less cardiovascular failure, respiratory failure, and acute kidney injury (AKI).

Despite the sizeable number of studies on hypotensive resuscitation in animal models and in humans, there is only one Cochrane-based review, and that review pertains only to the timing and volume of fluid administration in patients with bleeding. Moreover, in the present study, all types of hemorrhagic shock were included, including gastrointestinal bleeding. The results of this meta-analysis showed that there is no evidence for or against an early or larger volume of intravenous fluid administration in cases of uncontrolled hemorrhage.

Given that there is no meta-analysis related to studies comparing hypotensive to liberal fluid resuscitation, we decided to perform such an investigation. It is noteworthy that a large majority of the present literature had to be excluded from further analysis. This was mainly due to either the presence of irrelevant data and/or the lack of sufficient data. This highlights and supports the validity of the Cochrane approach.

Our analysis revealed that hypotensive resuscitation (i.e., limited fluid resuscitation) has beneficial effects on survival in traumatic hemorrhagic shock. Even in

\begin{tabular}{|c|c|c|c|c|c|c|c|c|c|c|}
\hline \multirow[b]{2}{*}{ Study or Subgroup } & \multicolumn{3}{|c|}{ Hypotensive resuscitation } & \multicolumn{3}{|c|}{ Normal resuscitation } & \multirow[b]{2}{*}{ Weight } & \multicolumn{2}{|l|}{ Mean Difference } & \multirow{2}{*}{$\begin{array}{l}\text { Mean Difference } \\
\text { IV, Random, } 95 \% \mathrm{Cl}\end{array}$} \\
\hline & Mean & SD & Total & Mean & SD & Total & & IV, Random, $95 \% \mathrm{Cl}$ & Year & \\
\hline ZHAO Yong-gang 2013 & 284.39 & 43.97 & 58 & 412.97 & 65.93 & 82 & $39.1 \%$ & $-128.58[-146.79,-110.37]$ & 2013 & 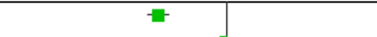 \\
\hline Chen Yuan-bing 2015 & 498 & 326 & 71 & 501 & 321 & 71 & $21.1 \%$ & $-3.00[-109.42,103.42]$ & 2015 & \\
\hline CHEN Mianzhan 2015 & 298 & 12 & 24 & 502 & 23 & 24 & $39.8 \%$ & $-204.00[-214.38,-193.62]$ & 2015 & - \\
\hline Total $(95 \% \mathrm{Cl})$ & & & 153 & & & 177 & $100.0 \%$ & $-132.09[-203.08,-61.10]$ & & \\
\hline \multicolumn{10}{|c|}{$\begin{array}{l}\text { Heterogeneity: } \text { Tau }^{2}=3268.68 ; \mathrm{Chi}^{2}=60.95, \mathrm{df}=2(\mathrm{P} \approx 0.00001) ;\left.\right|^{2}=97 \% \\
\text { Test for overall effect: } Z=3.65(\mathrm{P}=0.0003)\end{array}$} & $\begin{array}{ccccc}-200 & -100 & 0 & 100 & 200 \\
\text { Favours [experimental] } & \text { Favours [control] }\end{array}$ \\
\hline
\end{tabular}




\begin{tabular}{|c|c|c|c|c|c|c|c|c|c|c|}
\hline \multirow[b]{2}{*}{ Study or Subgroup } & \multicolumn{2}{|c|}{ Hypotensive } & \multicolumn{2}{|c|}{ Normal } & \multicolumn{2}{|r|}{ Risk Ratio } & \multirow{2}{*}{\multicolumn{4}{|c|}{$\begin{array}{c}\text { Risk Ratio } \\
\text { M-H. Random. } 95 \% \text { CI }\end{array}$}} \\
\hline & Events & Total & Events & Total & Weight & M-H, Random, $95 \% \mathrm{Cl}$ & & & & \\
\hline Bickell WH. 1994 & 3 & 289 & 8 & 309 & $13.0 \%$ & $0.40[0.11,1.50]$ & 1994 & $\square$ & E & \\
\hline WANG Mei-tang 2007 & 7 & 57 & 3 & 32 & $13.4 \%$ & $1.31[0.36,4.72]$ & 2007 & & & \\
\hline HUA Li-dian 2010 & 6 & 48 & 6 & 40 & $16.5 \%$ & $0.83[0.29,2.38]$ & 2010 & & & \\
\hline CHEN Mu-hu 2013 & 7 & 45 & 5 & 44 & $16.3 \%$ & $1.37[0.47,3.99]$ & 2013 & & $=$ & \\
\hline ZENG Fan-yuan 2014 & 2 & 57 & 2 & 57 & $7.7 \%$ & $1.00[0.15,6.86]$ & 2014 & & & \\
\hline CHEN Mianzhan 2015 & 4 & 24 & 5 & 24 & $14.6 \%$ & $0.80[0.24,2.62]$ & 2015 & & - & \\
\hline Schreiber 2015 & 22 & 96 & 5 & 95 & $18.5 \%$ & $4.35[1.72,11.02]$ & 2015 & & & \\
\hline Total $(95 \% \mathrm{Cl})$ & & 616 & & 601 & $100.0 \%$ & $1.19[0.65,2.21]$ & & & & \\
\hline Total events & 51 & & 34 & & & & & & & \\
\hline \multicolumn{6}{|c|}{$\begin{array}{l}\text { Heterogeneity: Tau }=0.31 ; \mathrm{Chi}^{2}=11.06, \mathrm{df}=6(\mathrm{P}=0.09) ; \mathrm{F}^{2}=46 \% \\
\text { Test for overall effect: } Z=0.57(\mathrm{P}=0.57)\end{array}$} & & & $\begin{array}{ccc}0.01 & 0.1 \\
\text { Favours experimental }\end{array}$ & $\begin{array}{c}10 \\
\text { Favours control }\end{array}$ & $100^{1}$ \\
\hline
\end{tabular}

the blood product based resuscitation era, all the literature still shows significant survival benefits [1013]. Hypotensive resuscitation is also associated with a significantly lower amount of fluid resuscitation and packed red cell transfusion, and a significantly lower incidence of acute respiratory distress syndrome and multiple organ dysfunction. In contrast, no significant difference was observed between resuscitation methods relative to the incidence of acute kidney injury. Moreover, we were not able to identify any report of renal replacement therapy and/or long-term dialysis in traumatic hemorrhagic shock patients.

The subgroup analysis that we performed showed a mortality benefit of hypotensive resuscitation in traumatic hemorrhagic shock with coexisting traumatic brain injury. This might alert readers to carefully interpret the reported findings from Gong Hong-chang et al. and LIU Wei-zheng et al., whose studies both maintained low normal blood pressure (SBP 90 $\mathrm{mmHg}$ or MAP $60-70 \mathrm{mmHg}$ ). Meanwhile, LIU Yu et al. maintained SBP $70 \mathrm{mmHg}$, which truly met the definition of hypotensive resuscitation. However, the data is not compelling enough to strongly recommend hypotensive resuscitation in traumatic hemorrhagic shock patients with traumatic brain injury, and there were no reported data on the functional outcomes after this strategy.

This study supports the use of hypotensive resuscitation, not only in penetrating wound patients, but also in other types of traumatic injuries. This significant finding was based on low heterogeneity. However, the limitations of this analysis include the fact that some clinical and methodological heterogeneities between the studies cannot be ruled out, and there may be some overtime bias. Despite significant publication bias shown by an asymmetrical funnel plot and Egger test, the trim and fill method also showed a statistically significant mortality benefit from the hypotensive strategy. Although a large, multi-center, randomized controlled trial should be conducted, the likelihood of such an approach succeeding given the present literature (including the present review) seems unlikely.

\begin{tabular}{|c|c|c|c|c|c|c|c|c|c|c|}
\hline \multirow[b]{2}{*}{ Study or Subgroup } & \multicolumn{2}{|c|}{ Hypotensive } & \multicolumn{2}{|c|}{ Normal } & \multicolumn{3}{|c|}{ Risk Ratio } & \multirow{2}{*}{\multicolumn{3}{|c|}{$\begin{array}{c}\text { Risk Ratio } \\
\text { M-H, Random, } 95 \% \mathrm{Cl} \\
\end{array}$}} \\
\hline & Events & Total & Events & Total & Weight & M-H, Random, $95 \% \mathrm{Cl}$ & Year & & & \\
\hline Bickell WH. 1994 & 3 & 289 & 8 & 309 & $4.9 \%$ & $0.40[0.11,1.50]$ & 1994 & & - & \\
\hline WANG Mei-tang 2007 & 10 & 57 & 10 & 32 & $14.5 \%$ & $0.56[0.26,1.20]$ & 2007 & & & \\
\hline WANG Aitian 2010 & 7 & 53 & 18 & 53 & $13.7 \%$ & $0.39[0.18,0.85]$ & 2010 & & & \\
\hline HUA Li-dian 2010 & 8 & 48 & 14 & 40 & $14.6 \%$ & $0.48[0.22,1.02]$ & 2010 & & & \\
\hline LI Wenhao 2012 & 7 & 63 & 19 & 63 & $13.4 \%$ & $0.37[0.17,0.81]$ & 2012 & & & \\
\hline CHEN Mu-hu 2013 & 5 & 45 & 13 & 44 & $9.5 \%$ & $0.38[0.15,0.97]$ & 2013 & & & \\
\hline WANG Xiao-guo 2014 & 4 & 41 & 11 & 40 & $7.5 \%$ & $0.35[0.12,1.02]$ & 2014 & & & \\
\hline ZENG Fan-yuan 2014 & 3 & 57 & 3 & 57 & $3.5 \%$ & $1.00[0.21,4.75]$ & 2014 & & & \\
\hline WEN Zhen-jie 2015 & 3 & 29 & 5 & 22 & $4.9 \%$ & $0.46[0.12,1.70]$ & 2015 & & - & \\
\hline YAO Jian-hui 2015 & 7 & 43 & 15 & 43 & $13.5 \%$ & $0.47[0.21,1.03]$ & 2015 & & & \\
\hline Total $(95 \% \mathrm{Cl})$ & & 725 & & 703 & $100.0 \%$ & $0.44[0.33,0.59]$ & & & & \\
\hline Total events & 57 & & 116 & & & & & & & \\
\hline $\begin{array}{l}\text { Heterogeneity: } \operatorname{Tau}^{2}=0 \\
\text { Test for overall effect: } Z\end{array}$ & $\begin{array}{l}00 ; \mathrm{Chi}^{2}= \\
=5.48(\mathrm{P}=\end{array}$ & $\begin{array}{l}2.10, d f \\
0.0000\end{array}$ & $=9(P=$ & $0.99) ; 1^{2}$ & $=0 \%$ & & & $0.01 \quad 0.1 \quad 1$ & $\begin{array}{c}10 \\
\text { Favours control }\end{array}$ & 100 \\
\hline
\end{tabular}




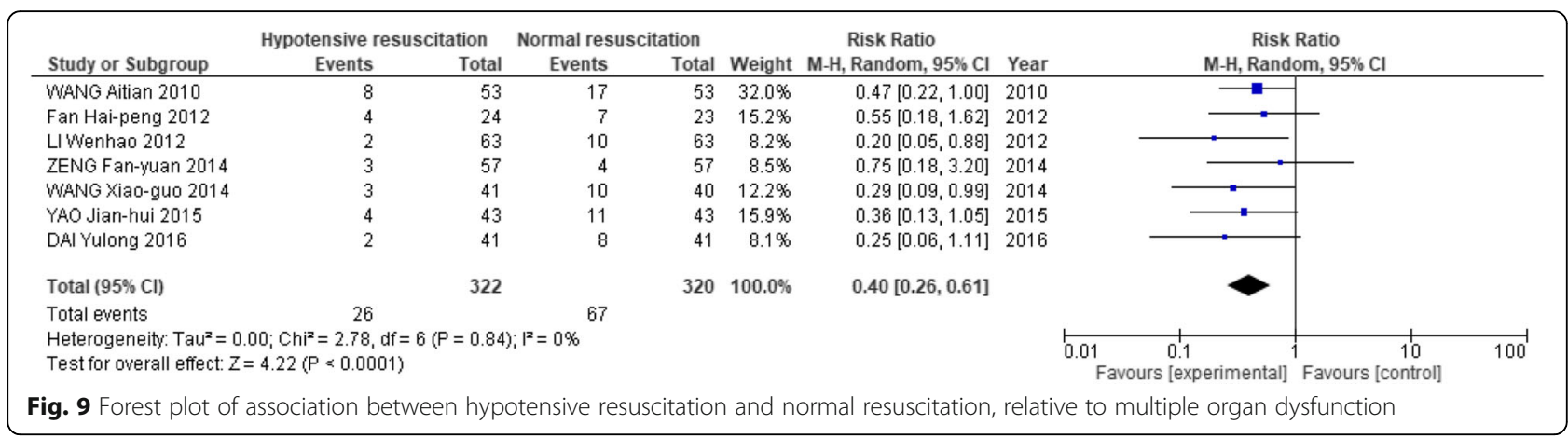

\section{Conclusions}

The results of this meta-analysis revealed a significant benefit of hypotensive resuscitation relative to mortality in traumatic hemorrhagic shock patients. Moreover, hypotensive resuscitation was found to be a significantly more effective strategy than traditional fluid resuscitation in terms of acute respiratory distress syndrome and multiple organ dysfunction.

\section{Acknowledgements}

The authors gratefully acknowledge Patompong Ungprasert of the Division of Clinical Epidemiology, Department of Research and Development, and Weerapat Owattanapanich of the Division of Hematology, Department of Medicine, both of the Faculty of Medicine, Siriraj Hospital, for assistance with the statistical analysis.

\section{Funding}

This was an unfunded study.

\section{Authors' contributions}

$\mathrm{NO}$ and TB reviewed, extracted and recorded data. KC made consensus in final decision on selected literatures. JS processed manuscript. All authors read and approved the final manuscript.

\section{Competing interests}

All authors declare that there are no personal or professional conflicts of interest, and there has been no financial support from the companies that produce and/ or distribute the drugs, devices, or materials described in this report.

\section{Publisher's Note}

Springer Nature remains neutral with regard to jurisdictional claims in published maps and institutional affiliations.

\section{Author details}

'Division of Trauma Surgery, Department of Surgery, Faculty of Medicine, Siriraj hospital, Mahidol University, 2 Wanglang Road, Bangkok Noi, Bangkok 10700, Thailand. ${ }^{2}$ Department of Surgery, Division of Surgical Critical Care and Trauma, Faculty of Medicine, Chiang Mai University, Chiang Mai, Thailand. ${ }^{3}$ Division of Vascular Surgery, Department of Surgery, Faculty of Medicine, Thammasat University, Pathumthani, Bangkok, Thailand.

Received: 11 September 2018 Accepted: 27 November 2018 Published online: 17 December 2018

\section{References}

1. Kauvar DS, Lefering R, Wade CE. Impact of hemorrhage on trauma outcome: an overview of epidemiology, clinical presentations, and therapeutic considerations. J Trauma. 2006;60(6 Suppl):S3-11.

2. Bickell WH, Wall MJ Jr, Pepe PE, Martin RR, Ginger VF, Allen MK, et al. Immediate versus delayed fluid resuscitation for hypotensive patients with penetrating torso injuries. N Engl J Med. 1994;331:17.

3. Bouglé A, Harrois A, Duranteau J. Resuscitative strategies in traumatic hemorrhagic shock. Ann Intensive Care. 2013;3:1.
4. Oh S-C, Bang SU, Kang B-G. The effect of induced hypotension on the perioperative bleeding and transfusion in the bipolar hemiarthroplasty of hip: retrospective study for four years. Korean J Anesthesiol. 2013;65(6 Suppl):S41-3.

5. Sharrock NE, Mineo R, Urquhart B, Salvati EA. The effect of two levels of hypotension on intraoperative blood loss during total hip arthroplasty performed under lumbar epidural anesthesia. Anesth Analg. 1993;76:3.

6. Donald JR. Induced hypotension and blood loss during surgery. J R Soc Med. 1982;75:3.

7. Salmasi V, Maheshwari K, Yang D, Mascha EJ, Singh A, Sessler DI, et al. Relationship between intraoperative hypotension, defined by either reduction from baseline or absolute thresholds, and acute kidney and myocardial injury after noncardiac SurgeryA retrospective cohort analysis. Anesthesiology. 2017;126:1.

8. Sun LY, Wijeysundera DN, Tait GA, Beattie WS. Association of intraoperative hypotension with acute kidney injury after elective noncardiac surgery. Anesthesiology. 2015;123(3).

9. Walsh M, Devereaux PJ, Garg AX, Kurz A, Turan A, Rodseth RN, et al. Relationship between intraoperative mean arterial pressure and clinical outcomes after noncardiac SurgeryToward an empirical definition of hypotension. Anesthesiology. 2013;119:3.

10. Dutton RP, Mackenzie CF, Scalea TM. Hypotensive resuscitation during active hemorrhage: impact on in-hospital mortality. J Trauma. 2002;52(6).

11. Carrick MM, Morrison CA, Tapia NM, Leonard J, Suliburk JW, Norman MA, et al. Intraoperative hypotensive resuscitation for patients undergoing laparotomy or thoracotomy for trauma: early termination of a randomized prospective clinical trial. J Trauma Acute Care Surg. 2016;80:6.

12. Morrison CA, Carrick MM, Norman MA, Scott BG, Welsh FJ, Tsai P, et al. Hypotensive resuscitation strategy reduces transfusion requirements and severe postoperative coagulopathy in trauma patients with hemorrhagic shock: preliminary results of a randomized controlled trial. J Trauma. 2011;70(3):652-63.

13. Schreiber MA, Meier EN, Tisherman SA, Kerby JD, Newgard CD, Brasel K, et al. A controlled resuscitation strategy is feasible and safe in hypotensive trauma patients: results of a prospective randomized pilot trial. J Trauma Acute Care Surg. 2015;78:4

14. Jadad AR, Moore RA, Carroll D, Jenkinson C, Reynolds DJ, Gavaghan DJ, et al. Assessing the quality of reports of randomized clinical trials: is blinding necessary? Control Clin Trials. 1996;17(1):1-12.

15. Stang A. Critical evaluation of the Newcastle-Ottawa scale for the assessment of the quality of nonrandomized studies in meta-analyses. Eur J Epidemiol. 2010;25(9):603-5.

16. Higgins JP, Thompson SG, Deeks JJ, Altman DG. Measuring inconsistency in meta-analyses. BMJ. 2003;327:7414.

17. Mianzhan CHEN. Analysis on the efficacy of limited fluid resuscitation of traumatic hemorrhagic shock. China Academic Journal. 2015;22:3.

18. Mu-hu CHEN, Wu ZHONG, Ying-chun HU. The study on limited fluid resuscitatin patients with traumatic shock. Sichuan Medical Journal. 2013;34:10.

19. Yuan-bing C, Bin L, Ai-guo Z, Qun-pei L, Yan-wen Y, Yan H. The application of limited fluid resuscitation in first aid of hemorrhagic traumatic shock. J Hunan Normal Univ. 2015;12:1.

20. Yulong DAl. Effect of limited fluid resuscitation on prognosis of patients with severe closed traumatic hemorrhagic shock. J Liaoning Medical University. 2016;37:1.

21. Hai-peng F, Yao-jian W, Zhi-hao Y. Clinical application of limited fluid resuscitation in treatment before operation of hepatic and splenic injury and haemorrhagic shock. Clin J Med Offic. 2012;40:4. 
22. Hai-peng FAN, Mao-xing YUE, Yao-jian WU. Early therapeutic effects of limited fluid resuscitation on severe pelvic fracture combined with hemorrhagic shock. J Trauma Surg. 2011;13:5.

23. Li-dian HUA, Yan-yang TU, Jian-fang FU, Jian LIN, Hao WANG. Application of limited fluid resuscitation in patients with severe multiple trauma hemorrhagic shock. Progress in Modern Biomedicine. 2010;10:13.

24. Ting HUANG, Yincan ZHANG. Analysis of the therapeutic effect of limited fluid resuscitation in hemorrhagic shock patients. China Modern Doctor. 2015;53:11.

25. Wenhao LI, Hongfeng LIN, Xuebiao DENG. Clinical discussion of limited fluid resuscitation on hemorrhagic traumatic shock without controlling bleeding. China Academic Journal. 2012;19:9.

26. Aitian WANG, Jingli GAO, Xiaolan LI, Shuohua CHEN, Hui ZHANG, Yujie MA, et al. The significance of APACHE II and IL-6 in patients with traumatic hemorrhagic shock by limited fluids resuscitation. Tianjin Med J. 2010;38:11.

27. Fengyong $W$. Efficacy of limited fluid resuscitation in the early treatment of patients with active hemorrhagic shock. Henan Meidcal Research. 2016;25:3.

28. WANG M-t, MEl b, HE J, HUO Z-I. Effect of preoperative limited fluid resuscitation to the patients with traumatic shock. J Med Coll PLA. 2007;22(4).

29. Xiao-guo WANG, Zi-li L, Guo-feng WEl. Diagnosis and treatment of traumatic hemorrhagic shock caused by rupture of the liver and spleen on early fluid resuscitation. J Hepatobiliary Surg. 2014;22:4.

30. Zhen-jie WEN, Jian-ling LIU, Jun CHEN. Comparison of application effects by hypertonic saline fluid resuscitation, limited fluid resuscitation and conventional fluid resuscitation in traumatic hemorrhagic shock. China Prac Med. 2015:10:15.

31. Guoping XU. Clinical observation on limited fluid resuscitation in the treatment of uncontrolled hemorrhagic shock. Chinese Journal of Disaster Medicine. 2015;3:5

32. Jian-hui YAO, Jiang-hong LU. A comparative study on the clinical effect of limited fluid resuscitation and active fluid resuscitation in the treatment of patients with mulitple trauma and hemorrhagic shock. Chinese Journal of Frontier Medicine. 2015;7:6.

33. Fan-yuan ZENG, Zeng-bin DENG, min-jian HU, Jian-xi YANG, Chao-fan HE, Jionglin LIANG, et al. Clinical observation of limited fluid resuscitation on preoperative uncontrolled hemorrhagic shock. J Chin Pract Diagn Ther. 2014;28:1.

34. Yong-gang ZHAO. The clinical effect analysis of limited fluids resuscitation in treatment of hemorrhagic shock. Medical Innovation of China. 2013;10:36.

35. ZHENG Wei-hua, WANG Xin-liang, XU Hua. Effects of limited fluid resuscitation in treatment of hemorrhagic traumatic shock. China journal of emergency resuscitation and disaster Medicine 2007;2:9.

36. Duval S, Tweedie R. Trim and fill: a simple funnel-plot-based method of testing and adjusting for publication bias in meta-analysis. Biometrics. 2000; 56(2):455-63.

37. Rezende-Neto JB, Rizoli SB, Andrade MV, Ribeiro DD, Lisboa TA, Camargos $E R$, et al. Permissive hypotension and desmopressin enhance clot formation. J Trauma. 2010;68(1):42-50

38. Geeraedts LM Jr, Kaasjager HA, van Vugt AB, Frolke JP. Exsanguination in trauma: a review of diagnostics and treatment options. Injury. 2009;40(1).

Ready to submit your research? Choose BMC and benefit from:

- fast, convenient online submission

- thorough peer review by experienced researchers in your field

- rapid publication on acceptance

- support for research data, including large and complex data types

- gold Open Access which fosters wider collaboration and increased citations

- maximum visibility for your research: over $100 \mathrm{M}$ website views per year

At $\mathrm{BMC}$, research is always in progress.

Learn more biomedcentral.com/submissions 